\title{
PENGELOLAAN PROGRAM STUDI DESAIN DAN TEKNOLOGI SEPATU DI AKADEMI TEKNOLOGI KULIT YOGYAKARTA
}

\author{
Vertasius Sanjaya Nugraha \\ Akademi Teknologi Kulit Yogyakarta \\ vesanug@yahoo.co.id \\ Herminarto Sofyan \\ Universitas Negeri Yogyakarta \\ hermin@uny.ac.id
}

\begin{abstract}
Abstrak
Penelitian bertujuan untuk: (1) mendapatkan informasi pengelolaan Program Studi (Prodi) Desain dan Teknologi Sepatu (DTS) di Akademi Teknologi Kulit (ATK) Yogyakarta,(2) mengetahui kesesuaian kurikulum Prodi DTS dengan dunia usaha atau industri (DUDI), dan (3) mengetahui kepuasan lulusan atas pengetahuan dan ketrampilan yang diperolehnya. Jenis penelitian ini adalah penelitian kualitatif dengan pendekatan studi kasus. Hasil penelitian ini adalah: (1) Kedudukan Prodi DTS berada dibawah direktur ATK, akan tetapi tanggung jawab, tugas dan wewenang secara langsung berada dibawah PD (Pembantu Direktur) 1 yang membidangi akademik atau pendidikan. Pengelola Prodi DTS meliputi: Ketua Prodi, Sekretaris Prodi, dan Kepala workshop. Ketua Prodi membawahi dosen, teknisi dan laboran. Tanggung jawab, tugas, dan wewenang Prodi hanya meliputi hal-hal yang terkait proses KBM teori maupun praktik;(2) Kurikulum Prodi DTS berbasis kompetensi yang disesuaikan dengan kebutuhan DUDI. Peninjauan kurikulum dilaksanakan dalam jangka waktu 4 tahunan. Hasil penelitian yang diambil dari pernyataan responden, yakni para mahasiswa tingkat akhir, dan alumni menyatakan bahwa kurikulum Prodi DTS sudah sesuai dengan DUDI. (3) Hasil penelitian mengungkapkan responden menyatakan puas akan pengetahuan dan ketrampilan dari Prodi DTS ATK Yogyakarta.
\end{abstract}

Kata Kunci: Pengelolaan Program Studi Desain dan Teknologi Sepatu

\section{Abstract}

This study aims to: (1) obtain information about the management of the Study Program of Shoe Design and Technology (SDT) in the Leather Technology Academy (LTA) of Yogyakarta, (2) find out the relevance of the curriculum to the industrial or business sector, and (3) investigate the graduates' satisfaction of knowledge and skills that they obtain from the institution. It was an evaluation study employing the qualitative approach. It was not intended to test whether a hypothesis was accepted or rejected but it was focused on the data collection to describe the actual conditions in the field. The results of the study show that: (1) The position of the study program in the organizational structure is under the Director of LTA. However, the coordination of responsibility, duty, and authority is directly under the Vice Dean (VD) I in charge of academic or educational affairs. The managerial board of the study program consists of the Head of the Study Program, the Secretary, and the Coordinator of the Workshop. In the job specification, the Head of the Study Program also supervises the lecturers, technicians, and laboratory personnel. (2) The curriculum implemented in the study program is competency-based with an objective of producing graduates with competencies demanded by the industry; the curriculum is periodically reviewed in four years. The results of the study based on the statements from the respondents, show that the curriculum in the study program is already relevant to the needs. (3) The results of the study based on the statements from the respondents, show that they are satisfied with the skills/competencies acquired or learned in the Study Program of SDT in LTA.

Keywords: Study Program of Shoe Design and Technology, management 


\section{PENDAHULUAN}

Program studi Desain dan Teknologi Sepatu (DTS) Akademi Teknologi Kulit (ATK) Yogyakarta dalam wilayah kerjanya berada dibawah Kementrian Perindustrian RI tentu saja mendapatkan pembinaan, dalam hal pengelolaan manajemen yang efektif dan efisien sehingga mampu membantu pemerintah dalam menyiapkan sumber daya manusia (SDM) yang unggul dan mampu bersaing dalam percaturan dunia pendidikan, ekonomi bidang usaha dan sebagainya. Mutu lembaga dipengaruhi oleh tahapan kegiatan yang saling berhubungan dengan proses misalnya perencanaan, pelaksanaan dan pengawasan. Pengelolaan program studi (prodi) itu akan dikatakan efektif jika tujuan pendidikan dapat tercapai yakni menciptakan lulusan yang dapat diterima di dunia kerja atau berwirausaha.

Dalam buku pedoman ATK (2004) menyebutkan bahwa penyelenggaraan Program Studi mempunyai tujuan, yaitu (1) menghasilkan lulusan tenaga ahli yang siap bersaing di pasar global dalam bidang desain dan teknologi sepatu/alas kaki; (2) meningkatkan penelitian aplikatif tentang perkembangan mode dan teknologi sepatu/alas kaki; (3) menjadi tempat rujukan dan belajar untuk pengetahuan desain dan teknologi sepatu/alas kaki sesuai dengan perkembangan teknologi dan trend mode; (4) menjadi sumber informasi mengenai fenomena dan problematika yang dihadapi industri sepatu/alas kaki sesuai dengan perkembangan teknologi; (5) meningkatkan net-working dengan dunia usaha, industri sepatu/alas kaki, alumni dan lembaga swadaya masyarakat serta memiliki kemampuan untuk berwirausaha dalam bidang tersebut dan tidak tertutup kemungkinan untuk bekerja pada perusahaan atau instansi pemerintah. Untuk mencapai tujuan tersebut perlu kerja sama dan hubungan yang baik antara mahasiswa dan dosen dalam pelaksanaan pembelajaran sesuai dengan pedoman yang berlaku. Dalam proses pembelajaran perlu interaksi antara dosen dan mahasiswa agar materi pelajaran dapat terserap oleh peserta didik dengan baik, proses belajar mengajar dapat terlaksana dengan lancar, dan program pembelajaran selesai tepat waktu.

Dalam pengelolaannya prodi DTS dikelola berdasarkan asas manajemen, yakni meliputi perencanaan, pengorganisasian dan pengkoordinasian, pelaksanaan dan pengendalian. Masing-masing prodi memiliki seperangkat kurikulum yang terbagi atas $40 \%$ sampai dengan $45 \%$ untuk perkuliahan teori dan 55\% sampai dengan $60 \%$ digunakan untuk perkuliahan praktik. Untuk mendukung ketercapaian pelaksanaan kurikulum yang melebihkan proporsi pelaksanaan pembelajaran praktik, maka prodi DTS secara bertahap melengkapi dan menambah peralatan maupun alat-alat praktik yang ada di laboratorium praktik atau workshop.

Data penelusuran mahasiswa dan lulusan yang telah dilakukan oleh bagian akademik ATK dalam laporan administrasi akademik tanggal 26 sepetember tahun 2011 menyebutkan dari sejumlah 86 mahasiswa program reguler yang sudah lulus, terpantau sebanyak 17 orang telah bekerja pada industri, 10 orang berwirausaha; dan 7 orang melanjutkan studi. Sementara data 2012 menyebutkan bahwa dari sejumlah 46 mahasiswa prodi DTS yang telah diwisuda atau yang telah lulus baru 11 lulusan yang terserap pada dunia industri atau usaha. Dengan demikian permasalahannya adalah sebagian besar lulusan prodi DTS belum mampu mandiri atau berwirausaha, dan masih sedikit lulusan yang dihasilkan oleh prodi DTS yang mampu terserap oleh dunia usaha.

Dari berbagai masalah diatas maka penelitian ini mencoba untuk mengungkap: pengelolaan Prodi DTS di ATK Yogyakarta, (2) kesesuaian kurikulum Prodi DTS dengan dunia industri atau usaha, dan (3) kepuasan lulusan atas pengetahuan dan ketrampilan yang mereka peroleh dari Prodi DTS ATK Yogyakarta.

Pengelolaan bisa berarti manajemen, sebagaimana disebutkan dalam terjemahan bahasa inggris yang mengartikan management dengan arti tata pimpinan atau pengelolaan. Menurut Hasibuan Malayu (2003:1) manajemen berasal dari kata to manage yang berarti mengatur. Pengaturan dilakukan melalui proses dan diatur berdasarkan urutan fungsi-fungsi manajemen. Jadi manajemen merupakan suatu proses untuk mewujudkan tujuan yang diinginkan. Menurut Suharsismi (2012:2) manajemen dalam arti luas menunjuk pada rangkaian kegiatan, dari perencanaan akan dilaksanakannya keg- 
iatan sampai penilaiannya. Manajemen dalam arti sempit, terbatas pada inti kegiatan nyata, mengatur atau mengelola kelancaran kegiatannya, mengatur kecekatan personil yang melaksanakan, pengaturan sarana pendukung, pengaturan dana dan lain-lain, tetapi masih terkait dengan kegiatan nyata yang sedang berlangsung. Senada dengan pendapat diatas, Griffin (2004:8) mengartikan manajemen adalah seperangkat aktivitas yang meliputi perencanaan dan pembuatan keputusan, pengorganisasian, kepemimpinan dan pengawasan, yang diarahkan pada organisasi manusia, keuangan, fisik, dan sumber-sumber informasi organisasi dengan maksud untuk mencapai tujuan-tujuan organisasi secara efektif dan efisien.

Stephen P. Robbins (2002:6) menjelaskan organisasi sebagai berikut: "Organisation a consciously coordinated social entity with a relatively identifiable boundary, that fuctions on a relatively continous basis to achieve a common goal or set of goals. Organisasi adalah unit sosial yang dengan sengaja diatur, terdiri atas dua orang atau lebih, yang berfungsi secara ralatif terus menerus untuk mencapai tujuan sasaran bersama.

Shoderbek, Cosier and Aplin (1988:8) mengartikan manajemen sebagai berikut :

management as a process of achieving organizational goals through others. The term "process" implies an orderly rather than a chaotic way of doing things. It also implies a series of actions, not just an isolated act. Manajemen adalah proses untuk mencapai tujuan organisasi melalui orang lain. Pengertian proses menjelaskan sebuah urutan yang jelas ketimbang cara yang sporadis dalam melakukan sesuatu. Frase ini juga menjelaskan urutan aksi bukan hanya sebuah aturan yang mengikat. Selanjutnya dikatakan "Management is also tasks, activities and functions. Irrespective of the labels attached to managing, the elements of planning, organizing, directing and controlling are essential". Manajemen juga diartikan sebagai tugas-tugas, kegiatan, dan fungsifungsi yang secara independent sesuai dengan fungsinya untuk mengelola, merencanakan, mengarahkan dan mengontrol adalah hal yang sangat penting.
Bush (2008:4) menyatakan bahwa: Management is maintaining efficiently and effectively current organisational arrangement. While managing well often exhibits leadership skills, the overall function is toword maintenance rather than change. I prise both managing and leading and attach no spesial value to either since different setting and times call for varied responses. Artinya manajemen adalah sebuah proses yang dilakukan untuk menjaga dan mempertahankan efisiensi dan efektivitas aktivitas atau arah pengaturan organisasi. Lebih lanjut Terry (2010:1) dalam bukunya yang dialih bahasakan oleh G.A. Ticoalu mengartikan manajemen sebagai suatu proses atau kerangka kerja yang melibatkan pengarahan suatu kelompok orang-orang kearah tujuantujuan organisasional atau maksud-maksud yang nyata. Manajemen adalah suatu kegiatan, pelaksanaannya adalah "managing" pengelolaan, sedangkan pelaksananya disebut manager.

Sementara itu Hikmat (2009:11) menyatakan manajemen adalah ilmu dan seni mengatur proses pemanfaatan sumberdaya manusia secara efektif yang didukung oleh sumber-sumber lainya dalam suatu organisasi untuk mencapai tujuan tertentu. Berdasarkan beberapa definisi tentang manajemen diatas dapat diambil beberapa kesimpulan sebagai berikut: (1) manajemen adalah gabungan ilmu pengetahuan dan kiat dan profesi; (2) manajemen adalah merupakan suatu proses yang sistematis, terkoordinasi dan kooperatif dalam memanfaatkan sumber daya manusia dan sumber-sumber lainnya; dan (3) manajemen terdiri dari tindakan-tindakan perencanaan, pengorganisasian, penggerakan dan pengendalian sumber daya manusia dan sumber daya lainnya untuk mencapai tujuan.

Pemerintah menentukan kebijakan nasional dan standar nasional pendidikan untuk menjamin mutu pendidikan nasional. Dalam kebijakan pendidikan nasional sebagaimana diatur UU No. 20 tahun 2003, dibedakan antara pengelolaan pendidikan dasar dan menengah dengan pengelolaan pendidikan tinggi. Pengelolaan satuan pendidikan dasar dan menengah dilakukan oleh pemerintah kabupaten/kota dengan berkoordinasi dengan pemerintah propinsi. Sedangkan pada pendidikan tinggi, perguruan 
tinggi atau program studi sendiri menentukan kebijakan dan memiliki otonomi dalam mengelola pendidikan pada lembaganya.

Berdasarkan peraturan tersebut di atas, pengelolaan program studi pada perguruan tinggi memiliki kebijakan dan otonomi dalam melakukan pengelolaan pendidikan. Sehingga manajemen atau pengelolaan program studi pada perguruan tinggi menerapkan fungsi manajemen secara umum, yang terdiri atas perencanaan, pengorganisasian, pergerakan dan pengawasan. Pengelolaan program studi adalah pendekatan sistemik untuk mengelola sumber daya, infrastruktur, proses dan atau kegiatan serta orang. Sistem pengelolaan fungsional dan operasional program studi mencakup perencanaan, pengorganisasian, penggerakan (actuating), dan kontrol atau pengawasan.

Pengelolaan Prodi DTS ATK Yogyakarta mengacu pada PP 60 th 1999 BAB VIII pasal 87, dan statuta ATK Yogyakarta Bab VI pasal 24. Struktur organisasi ATK terdiri atas: (1) Unsur Pimpinan terdiri atas Direktur dan para Pembantu Direktur; (2) Senat Akademi; (3) Unsur pelaksana akademi: program studi, laboratorium/ workshop, kelompok dosen dan Pusat Penelitian dan Pengabdian pada Masyarakat (P3M); (4) Unsur pelaksanaan administrasi: bagian administrasi akademik dan kemahasiswaan dan bagian administrasi umum; (5) Unsur penunjang: unit pelaksanaan teknis

Kurikulum pendidikan tinggi adalah seperangkat rencana dan pengetahuan mengenai isi maupun bahan kajian dan pelajaran serta cara penyampaiannya dan penilaiannya yang digunakan sebagai pedoman penyelenggaraan kegiatan belajar mengajar diperguruan tinggi (Mendiknas No.232/U/2000). Sukamto (1988:3) menyebutkan bahwa kurikulum merupakan kunci pokok atau komponen utama dalam usaha mengembangkan potensi peserta didik melalui program pendidikan. Kurikulum adalah serangkaian kegiatan yang harus dilakukan atau dialami oleh anak-anak atau anak muda dengan maksud mengembangkan kemampuan mengerjakan sesuatu termasuk dalam kehidupan orang dewasa dengan sebaikbaiknya, dan agar memiliki sifat yang seharusnya dimiliki oleh seorang dewasa dalam segala aspeknya.
Sedangkan kurikulum menurut Beane (1986:30) sebagai berikut: "Curriculum consists of all the means of instruction used by the school to provide opportunities for student learning experiences leading to desired learning out comes". Jadi dari pengertian di atas dapat diartikan bahwa, kurikulum merupakan serangkaian strategi pengajaran yang dipergunakan di sekolah untuk menyediakan kesempatan terwujudnya pengalaman belajar bagi peserta didik untuk mencapai hasil belajar yang diinginkan. Finch \& Crunkilton (1993:7) merumuskan, "Curriculum may be defined as the sum of the learning activities and experiences that a student has under the auspices or direction of the school ". Ini berarti kurikulum merupakan keseluruhan aktivitas dan pengalaman belajar yang harus dimiliki siswa dalam bimbingan dan arahan sekolah. Dengan demikian kurikulum itu sifatnya luas dan sebagai aktualisasinya adalah aktivitas pembelajaran.

Menurut Oliva (1992:9) " curriculum is perceived as a plan or program for all the experiences, which the learner encounter under the direction of the school ". Hal ini memandang kurikulum sebagai sebuah rencana atau program yang didalamnya berisi sejumlah kegiatan yang harus dialami peserta didik dibawah arahan sekolah. Menurut Oemar Hamalik (2011:16) kurikulum dipandang dalam tiga aspek yaitu: (1) kurikulum memuat isi dan materi pelajaran. Kurikulum adalah sejumlah mata ajaran yang harus ditempuh dan dipelajari oleh peserta didik untuk memperoleh sejumlah pengetahuan, (2) kurikulum sebagai rencana pembelajaran. Kurikulum adalah suatu program pendidikan yang disediakan untuk membelajarkan peserta didik, (3) kurikulum sebagai pengalaman belajar. Kurikulum tidak terbatas pada ruang kelas saja, melainkan mencakup juga kegiatan-kegiatan di luar kelas, selain itu kurikulum adalah seperangkat rencana dan pengaturan mengenai isi dan bahan pelajaran serta cara yang digunakan sebagai pedoman penyelenggaraan kegiatan belajar mengajar.

Berdasarkan pendapat di atas maka dapat disimpulkan bahwa kurikulum merupakan pedoman rencana pembelajaran, serangkaian 
strategi pembelajaran yang di dalamnya mencakup isi dan proses baik formal maupun informal dalam usaha menanamkan pada peserta didik mengenai pemahaman, pengembangan, maupun penanaman tentang sikap dalam pelaksanaan proses kegiatan pembelajarannya dibawah tanggung jawab sekolah. sehingga kurikulum perlu dijabarkan dan diaplikasikan kedalam kegiatan pembelajaran. Betapapun baiknya kurikulum kalau tidak didukung oleh guru yang mampu mengelola, tentu tidak akan berpengaruh pada perubahan.

Kurikulum disusun sebagai acuan penyelenggaraan proses kegiatan perkuliahan baik praktik maupun teori agar dapat terlaksana dengan baik sesuai dengan harapan peserta didik, maupun sesuai dengan harapan dunia kerja atau industri. Kurikulum yang baik akan dapat menciptakan kepuasan bagi pengguna atau pelanggan jasa pendidikan.

Fandy Tjiptono (2005:125) mengemukakan bahwa kualitas pelayanan internal akan mendorong terwujudnya kepuasan pelanggan internal dan tumbuhnya rasa memiliki diantara mereka. Pelanggan internal disini dapat diartikan sebagai individu atau unit yang menerima hasil (manfaat jasa) suatu proses dalam sistem atau organisasi. adapun kepuasan pelanggan internal disini dalam lingkup pendidikan di perguruan tinggi adalah mahasiswa atau peserta didik yang memanfaatkan jasa dari institusi pendidikan. Pelanggan yang dimaksudkan dalam penelitian ini adalah mahasiswa, alumni, dan pengguna lulusan atau dunia usaha yang menggunakan atau memanfaatkan jasa dari institusi pendidikan, yaitu program studi Desain dan Teknologi Sepatu Akademi Teknologi Kulit (ATK) Yogyakarta.

Oliver (1997:12) mendefinisikan tentang kepuasan pelanggan adalah sebagai evaluasi purna produk jasa atau barang, dimana persepsi terhadap kinerja, alternative produk atau jasa yang dipilih memenuhi atau melebihi harapan. Apabila persepsi terhadap kinerja tidak dapat memenuhi harapan, maka yang terjadi adalah ketidakpuasan. Kepuasan pelanggan ditentukan oleh persepsi pelanggan atas performance produk atau jasa dalam memenuhi harapan pelanggan. Pelanggan merasa puas apabila harapannya terpenuhi atau akan sangat puas jika harapannya terlampaui. Adapun Handi Irawan (2002:33) mengidentifikasikan lima faktor utama kepuasan pelanggan sebagai berikut: (1) Kualitas produk/jasa;(2) Biaya; (3) Kualitas Pelayanan; (4) Emosional; dan (5) Hubungan biaya dengan kemudahan mendapatkan jasa.

Berdasarkan kajian teori diatas, maka pertanyaan penelitian ini adalah sebagai berikut:

1. Bagaimanakah kedudukan Program Studi DTS di ATK Yogyakarta?

2. Bagaimana pengelolaan Program Studi DTS ATK Yogyakarta?

3. Bagaimanakah pengelolaan laboratorium praktek prodi DTS ?

4. Bagaimanakah pengelolaan SDM Prodi DTS ATK Yogyakarta?

5. Bagaimanakah struktur organisasi prodi DTS ATK Yogyakarta?

6. Apakah kurikulum Program Studi DTS ATK Yogyakarta sudah sesuai dengan dunia Industri atau dunia usaha?

7. Apakah lulusan dan pengguna lulusan prodi DTS ATK Yogyakarta puas atas pengetahuan dan keterampilan yang mereka peroleh dari Program Studi DTS di ATK Yogyakarta?

\section{METODE PENELITIAN}

\section{Jenis Penelitian}

Penelitian ini merupakan jenis penelitian kualitatif, yakni penelitian yang pengambilan datanya atau penjaringan fenomena dilakukan dari keadaan yang sewajarnya, alami atau natural. Pendekatan dalam penelitian ini menggunakan pendekatan studi kasus (case-studies), pendekatan penelitian studi kasus berusaha menggali data secara mendalam dengan objek yang spesifik. Tujuan pendekatan studi kasus dalam penelitian ini untuk mengetahui pengelolaan Program Studi DTS, kesesuaian kurikulum dengan dunia kerja, dan kepuasan lulusan, maka penelitian dapat dikategorikan sebagai penelitian evaluatif.

\section{Subjek Penelitian}

Dalam penelitian ini yang menjadi subyek penelitian adalah Program Studi DTS ATK Yogyakarta. Adapun responden yang dijadi- 
kan subjek penelitian adalah sebagai berikut, yakni: (1) ketua prodi atau Prodi Desain dan Teknologi Sepatu (DTS) ATK Yogyakarta, (2) sekretaris prodi DTS, ATK Yogyakarta, (3) Ketua atau kepala Workshop sepatu Prodi DTS, (4) mahasiswa tingkat akhir yang telah menyelesaikan praktik industri, (5) alumni yang telah bekerja baik pada instansi pemerintah maupun berwiraswsta. Penentuan jumlah responden ditentukan berdasarkan kebutuhan atau kecukupan data penelitian yang diperlukan dalam penelitian.

\section{Waktu Penelitian}

Dilaksanakan mulai bulan Agustus tahun 2012 sampai dengan bulan Maret 2013

\section{Teknik Pengumpulan Data}

Metode pengumpulan data yang digunakan dalam penelitian ini adalah wawancara, observasi, dan dokumentasi. Untuk menjamin diperolehnya derajat keperayaan, maka dilakukan trianggulasi. Trianggulasi adalah teknik pemeriksaan keabsahan data yang memanfaatkan suatu kejadian yang diluar data itu untuk keperluan pengecekan atau sebagai pembanding terhadap data-data yang ada.

\section{Teknik Analisis Data}

Teknik analisis data dalam penelitian ini mengikuti model analisis data interaktif, yakni proses analisis dilakukan bersamaan proses pengumpulan data. Dengan demikian analisis dilakukan sejak peneliti berada dilapangannya.

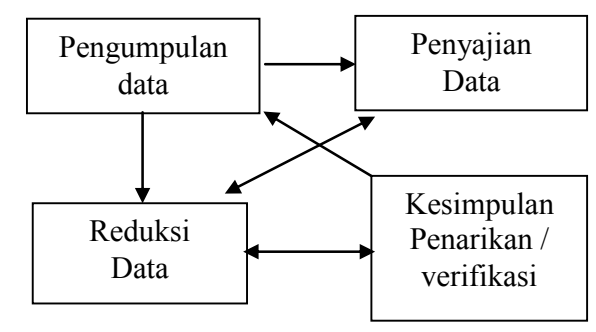

Gambar1. Skema Analisis Data

Ada tiga hal utama yang dikemukakan dalam gambar tersebut, yaitu: reduksi data, penyajian data dan penarikan kesimpulan sebagai sesuatu yang saling terkait pada saat sebelum, sesudah dan selama peneliti mengumpulkan data dalam bentuk yang sejajar untuk membangun wawasan umum yang disebut analisis.
Tiga hal tersebut dalam kegiatan analisis dan kegiatan pengumpulan data merupakan proses siklus dan interaktif. Selama mengumpulkan data juga dilakukan kegiatan reduksi data, penyajian data dan penarikan kesimpulan atau verifikasi selama waktu penelitian berlangsung.

\section{HASIL PENELITIAN DAN PEMBAHASAN}

Akademi Teknologi Kulit (ATK) merupakan unit pendidikan vokasi di bawah Pusat Pendidikan dan Pelatihan (Pusdiklat) Industri Kementerian Perindustrian RI yang bertugas mendidik tenaga Ahli Madya Teknologi Kulit (A.Md TK) yang mampu dan terampil di bidang industri kulit, produk kulit serta industri terkait. Dalam mengemban misi Tri Dharma Perguruan Tinggi (Pendidikan, Penelitian dan Pengabdian pada Masyarakat), ATK senantiasa berusaha berorientasi pada pemenuhan kebutuhan industri (industries demand). Kebutuhan industri tersebut diantaranya berupa: peningkatan kualitas sumber daya manusia (SDM); pengembangan teknologi; maupun pemecahan masalah yang dihadapi oleh industri.

Dengan mengintegrasikan kegiatan pendidikan, pelatihan, konsultasi dan produksi, maka peran ATK sebagai mitra utama industri kulit, sepatu/alas kaki, produk kulit dan industri terkait akan meningkat, melalui: pengembangan sistem pendidikan dan pelatihan industri terapan yang berbasis pada kebutuhan/ permintaan masyarakat industri, pengembangan institusi pendidikan dan pelatihan industri terapan yang mandiri (selffinancing), pengembangan jaringan kemitraan antara institusi pendidikan/ pelatihan dengan pelaku industri yang berbasis pada pemberdayaan masyarakat dan potensi daerah, pengembangan kapasitas tenaga kerja yang kompeten dan bersertifikat, serta pengembangan jaringan konsultasi bisnis dan usaha perdagangan.

\section{Pengelolaan Program Studi Desain dan Teknologi Sepatu (DTS)}

Amanat Undang-Undang Sistem Pendidikan Nasional (UU Sisdiknas) No. 20 tahun 2003 pada dasarnya adalah perubahan dalam tata kelola sistem pendidikan nasional yang di- 
arahkan pada peningkatan mutu serta relevansi dan effisiensi manajemen pendidikan untuk menghadapi globalisasi. Dalam rangka peningkatan mutu pendidikan tinggi maka tata kelola perguruan tinggi harus dirubah, yaitu: dari traditional learning ke knowledge creator and moral force; dari random planning ke strategic planning; dan dari comparative ke competitive. Adanya perubahan tata kelola perguruan tinggi tersebut, akan membawa institusi menjadi Good Corporate Governance (GCG). Pengertian GCG, adalah tata kelola korporasi yang memberikan jaminan atas hasil dari suatu proses dan sistem yang dialami dengan berlandaskan pada prinsip fairness, transparancy, responcibiliy, dan accounttability. Indikator utama dari GCG adalah; autonomy,competitiveness, organizational health, inovation, entrepreunership, stakeholders, control system and development.

Yang dimaksud pengelolaan prodi DTS disini adalah segala sesuatu yang berhubungan dengan pengelolaan proses perkuliahan baik teori maupun praktik yang dilaksanakan dan dikelola oleh pada Prodi DTS. Adapun pengelolaan Prodi yang dimaksud meliputi: (1) perencanaan, (2) pengorganisasian, (3) penggerakan atau pengarahan, dan (4) pengendalian.

\section{Perencanaan}

Perencanaan yang dilakukan oleh Prodi DTS secara umum mengacu dan mengikuti kebijakan perencaaan pengeloaan yang telah ditetapkan oleh Akademi. Adapun kebijakan pengelolaan perencanaan manajemen organisasi pada Prodi DTS secara khusus mengacu pada tanggung jawab, tugas, dan wewenang ditingkat Program Studi, yakni melakukan perencanaan program yang khusus berhubungan dengan pendidikan, dalam hal ini adalah pelaksanaan proses kegiatan belajar mengajar atau perkuliahan.

Perencanaan program yang berhubungan dengan perkuliahan, Prodi DTS bekerja dibawah koordinasi bidang pendidikan yakni dibawah wilayah kerja pembantu direktur 1 (PD.1) yang membawahi urusan pendidikan. Perencanaan pengelolaan pada tingkat Akademi atau bagian pendidikan adalah difokuskan pada peningkatan ektifitas pendidikan dan peningkatan mutu lulusan, diawali dengan peneri- maan mahasiswa baru dilanjutkan dengan Orientasi Wawasan Kampus (OWK), Pelatihan Remaja bertanggung Jawab, AMT, Perkuliahan, Ujian Mid Semester, Semester, Pembekalan Mahasiswa TK.Akhir Magang, Ujian Akhir dan Wisuda.

Untuk mencapai hasil yang optimal dari rencana program pengelolaan Program Studi Desain dan Teknologi Sepatu, Program Studi Desain dan Teknologi Sepatu mempunyai visi : Menjadi Program Studi yang siap bersaing di pasar global dalam bidang Desain dan Teknologi Sepatu atau alas kaki. Dan misi Prodi Desain dan Teknologi Sepatu (DTS): (a) Melaksanakan pendidikan dan pengajaran sesuai kurikulum berbasis kompetensi, Meningkatkan penelitian aplikatif tentang perkembangan mode, desain dan teknologi sepatu/alas kaki, (c) Menjadi tempat rujukan dan belajar untuk pengetahuan Desain dan Teknologi Sepatu/Alas kaki sesuai dengan perkembangan teknologi dan trend mode, (d) Menjadi sumber informasi mengenai fenomena dan problematika yang dihadapi industri sepatu/alas kaki sesuai dengan perkembangan ilmu pengetahuan dan teknologi, (e) Meningkatkan net-working dengan dunia usaha, industri sepatu/alas kaki, alumni dan lembaga swadaya masyarakat, (f) Menciptakan budaya wirausaha dalam rangka ikut menciptakan lapangan pekerjaan.

\section{Pengorganisasian}

Dinamisasi suatu organisasi dapat terlihat pada struktur organisasi dari suatu institusi, demikian juga dengan Program Studi Desain dan Teknologi Sepatu (DTS) telah mengalami beberapa kali perubahan untuk menyesuaikan dengan pengembangan institusi. Pada saat ini struktur organisasi yang diterapkan DTS berada di bawah struktur organisasi Akademi yakni ATK, yang mengacu pada Keputusan Menteri Perindustrian dan Perdagangan Nomor: 659/ MPP/Kep/10/2003 tanggal 21 Oktober 2003 tentang Statuta ATK

Kedudukan Prodi DTS dalam organisasi pengelolaannya berada dibawah direktur, sebagimana ditunjukkan dan struktur organisasi ATK. Prodi DTS pada Akademi Teknologi Kulit mulai eksis sejak tahun akademik 19951996 dan merupakan penjelmaan dari Jurusan 
Desain dan Teknologi Sepatu yang mulai dibuka pada tahun 1972. Perubahan nama prodi tersebut sejalan dengan kebutuhan pendidikan setingkat Akademi, yang mampu menghasilkan Sumber Daya Manusia (SDM) di sektor industri sepatu/alas kaki.

Pengelolaan organisasi Prodi DTS melekat pada Struktur organisasi yang ada di ATK. Prodi DTS dalam wilayah kerjanya berkedudukan sama dengan Prodi lain yang ada di ATK. Prodi DTS berada pada wilayah kerja Direktur. Lebih khusus Prodi DTS berada wilayah koordinasi kerja dari Pembantu Direktur 1 yang membawahi bagian pendidikan dan pengajaran. Dalam melaksanakan tugas pokok dan fungsinya, maka Direktur ATK dibantu oleh: Pembantu Direktur I Bidang Akademik; Pembantu Direktur II Bidang Administrasi Umum dan Keuangan; Pembantu Direktur III Bidang Kemahasiswaan; Pelaksana Akademik yang terdiri dari Ketua Program Studi, Kepala Workshop/Laboratorium, Kelompok Dosen, Ketua Unit Penelitian dan Pengabdian Pada Masyarakat (UP2M) dan Teknisi Laboratorium; Pelaksana Administrasi yang terdiri dari: Subbag Administrasi Akademik dan Kemahasiswaan dan Subbag Administrasi Umum dan Keuangan. Senat Akademik merupakan badan normatif yang berfungsi memberikan pertimbangan, mengontrol dan mengevaluasi kinerja pimpinan akademik.

\section{Penggerakan atau pengarahan}

Pengarahan adalah tindakan mengusahakan hubungan-hubungan kelakukan yang efektif antara orang-orang, sehingga mereka dapat bekerjasama secara efisiean. Dalam lingkup perguruan tinggi, tugas penggerakan adalah tugas memenfaatkan dan menggerakkan seluruh manusia yang bekerja pada suatu perguruan tinggi, agar masing-masing bekerja sesuai dengan tugasnya. Fungsi penggerakan atau pengarahan dalam sistem pengelolaan Program Studi Desain dan Teknologi Sepatu mempunyai peran penting, hal ini berkaitan dengan pola kepemimpinan yang sentralistik.

Penggerakan dan pengarahan diberikan pada saat sebelum pelaksanaan maupun ketika tugas sedang berlangsung. Dalam penyampaian pengarahan pimpinan atau ketua prodi biasa mengadakan rapat khusus pimpinan dan staf, serta para dosen. Pengarahan dapat berjalan efektif apabila didukung oleh karyawan dan dosen dalam kondisi loyalitas yang tinggi sehingga materi pengarahan itu dapat menjadi perhatian dosen dan karyawan selanjutnya bisa didiskusikan pelaksanaannya agar tugas dan arahan pimpinan dapat dikerjakan sebaik-baiknya.

Dalam pelaksanaan pengelolaan Prodi Desain dan Teknologi Sepatu, ketua prodi mengkoordinir pelaksaaan program pengelolaan prodi DTS dengan selalu merujuk pada usulan-usulan yang disampaikan pada awal tahun ajaran yang telah disetujui oleh jajaran PD. 1 dan direktur. Sehingga pelaksanaan program pengelolaan selalu mengacu pada perencanaan yang ditetapkan sesuai dengan tanggung jaw$a b$, tugas, dan wewenang. Dalam upaya pengendalian organisasi atau manajemen, pimpinan memerankan fungsinya sebagai pengambil keputusan yang pada hakekatnya adalah mempunyai kemampuan kerjanya dengan menggunakan kekuasaan. Pengendalian akan berjalan efektif apabila antara dosen, karyawan, maupun mahasiswa mematuhi tata tertib yang sudah digariskan dalam statuta ATK tahun 2003. Pendekatan yang dilakukan untuk memecahkan suatu masalah dilakukan secara kekeluargaan atau pendekatan situasional yang memfokuskan pada kesesuaian antara perilaku pemimpin dengan karakteristik situasional.

\section{Pengontrolan}

Pengendalian atau pengontrolan proses belajar mengajar maupun kegiatan lain dilakukan untuk mengetahui seberapa jauh hasil yang dicapai. Dalam upaya pengendalian ini pimpinan memerankan fungsinya sebagai pengambil keputusan yang pada hakekatnya adalah mempunyai kemampuan kerjanya dengan menggunakan kekuasaan. Pengendalian akan berjalan efektif apabila antara dosen, karyawan, maupun mahasiswa mematuhi tata tertib yang sudah digariskan dalam statuta 2003. Pendekatan yang dilakukan untuk memecahkan suatu masalah yaitu: secara kekeluargaan atau pendekatan situasional yang memfokuskan pada kesesuaian antara perilaku pemimpin dengan karakteristik situasional. Pendekatan kekeluargaan bukan berarti tidak ada ketegasan, karena pada setiap lembaga ada peraturan yang dipedomani 
dan dipatuhi. Pelanggaran tata tertib juga dikenakan sanksi secara bertahap bersifat edukatif tetapi penuh ketegasan.

Pengendalian atau pengontrolan mekanisme manajemen tentunya sesuai dengan hirarki kepemimpinan dan garis koordinasi. Artinya struktur dibawah memberikan pelaporan dan pertanggungjawaban pada struktur diatasnya, sebaliknya struktur diatas melakukan koordinasi dan pengawasan pada struktur yang ada dibawahnya. Seperti contoh mekanisme evaluasi atau kontrolnya yakni bahwa prodi harus menyampaikan laporan tahunan kepada bidang pendidikan. Pengendalian akan berjalan efektif apabila semua unit kerja berjalan sesuai tugas yang sudah diatur dalam statuta. Pelanggaran tata tertib dikenakan sanksi secara bertahap bersifat edukatif tetapi penuh ketegasan.

\section{Pengelolaan SDM}

Dalam rangka meningkatkan kualitas sumber daya manusia (SDM), lebih khusus tenaga pengajar atau dosen Program Studi DTS, Akademi Tekonologi Kulit (ATK) Yogyakarta memberikan kesempatan kepada seluruh tenaga pengajar atau dosen untuk melanjutkan studi melalui pendidikan formal maupun magang. Selain itu ATK juga mengikut sertakan baik tenaga pengajar, staf dan karyawan dalam program pelatihan atau Diklat-Diklat (Short training), baik diklat struktural, fungsional maupun Teknis. Selain itu mengikut sertakan dalam Seminar atau ceramah dan Workshop yang diselenggarakan oleh Kementrian Perindustrian maupun instansi-instansi lain.

\section{Pengelolaan Workshop}

Pengelolaan laboratorium atau Workshop sepatu di Program Studi DTS di pimpin atau dikepalai oleh seorang ketua atau Ka. Workshop. Dalam menjalankan tugasnya seorang Ka. Workshop berada di bawah koordinasi ketua Program Studi, sehingga dalam pelaksanaan tugasnya seorang kepala workshop selalu berkoordinasi dengan ketua Program Studi dan dosen-dosen Program Studi untuk menjamin pelaksanaan kegiatan belajar mengajar (KBM) praktik berjalan lancar. wilayah kerja yang berhubungan dengan tanggungjawab, tugas, dan wewenang seorang Kepala Workshop telah dijabarkan dalam manual mutu ATK. Pengelolaan workshop praktik Program Studi Desain dan Teknologi Sepatu (DTS) meliputi kegiatan perawatan, perbaikan, dan pengusulan penambahan.

Sarana pembelajaran praktik yang ada di prodi DTS meliputi : (1) Workshop Atasan sepatu; (2) Workshop Bawahan sepatu; (3) Workshop Jahit; (4) Workshop acuan sepatu; (5) Ruang Pengembangan Desain; (6) Ruang Gambar; dan (7) Ruang Pola. Adapun beberapa jenis mesin yang digunakan untuk pembelajaran praktik Prodi DTS adalah sebagai berikut : Lasting toe machine, Back part machine, Lasting Back machine, Heating Conveyor, Ironing machine, Prees Bottom Hidrolyck, kompresor, Seving machine Flet Beth, Post Beth, Cilinder, single needle, double needle, Bending, Strooble, Embos Machine (stamping), Roughing Machine, Skiving Machine, Foulding machine, Spliting machine.

\section{Kesesuaian Kurikulum Program Studi DTS dengan Dunia Usaha/ Industri}

Dalam pelaksanan sistem pendidikan di Program Studi DTS ATK Yogyakarta perlu memiliki perencanaan pembelajaran yang disusun secara sistematis untuk mencapai tujuan. Sistem perencanaan pembelajaran atau perkuliahan yang dimaksud adalah kurikulum. Dimana kurikulum dapat diartikan sebagai suatu rencana yang sengaja dirancang untuk mencapai sejumlah tujuan pendidikan. Sejalan dengan perubahan tata kelola Sistem Pendidikan Nasional, Program Studi DTS ATK Yogyakarta telah melakukan beberapa upaya dan kebijakan, antara lain berupa: menerapkan kurikulum berbasis kompetensi dengan tujuan untuk menghasilkan lulusan yang mempunyai kemampuan sesuai dengan kompetensi yang dibutuhkan industri, melaksanakan penelitian yang aplikatif dan inovatif agar dapat diterapkan industri, menyediakan jasa pelayanan teknis atau konsultasi dan pelatihan untuk tenaga kerja di industri, serta melakukan kegiatan usaha produksi.

Dalam rangka memenuhi kebutuhan spesifikasi unggulan tentang teknologi kulit dan produk kulit /sepatu yang akan menentukan kualifikasi lulusan, maka prodi DTS telah 
Tabel 1. Kurikulum Prodi DTS

\begin{tabular}{lcccccccc}
\hline \multirow{2}{*}{ MATA KULIAH } & \multicolumn{3}{c}{ JUMLAH MATA KULIAH } & \multicolumn{4}{c}{ JUMLAH SKS } \\
\cline { 2 - 9 } & K & PA & PU & $\Sigma$ & K & PA & PM & $\Sigma$ \\
\hline MPK & 3 & 1 & - & 4 & 9 & 2 & - & 11 \\
MKK & 11 & 4 & - & 15 & 19 & 10 & - & 29 \\
MKB & 5 & 18 & - & 23 & 8 & 57 & - & 65 \\
MPB & 2 & 2 & - & 4 & 4 & 4 & - & 8 \\
MBB & 1 & - & - & 1 & 2 & - & - & 2 \\
JLH & 22 & 25 & - & 47 & 42 & 73 & - & 115 \\
\hline
\end{tabular}

Keterangan:

$\mathrm{K}=$ Kuliah $; \mathrm{PA}=$ Praktik $; \mathrm{PU}=$ Praktikum

MPK = Pengembangan Kepribadian

MKK = Keilmuan dan Keterampilan

$\mathrm{MKB}=$ Keahlian Berkarya

MPB = Perilaku Berkarya

$\mathrm{MBB}=$ Berkehidupan Bermasyarakat

\section{Perbandingan}

Mata Kuliah Teori : Praktik $\rightarrow 40: 60$.

menerapkan kurikulum berbasis kompetensi yang berlandaskan Production Based Education and Training (PBET). Prodi DTS yang berada diwilayah kerja ATK sebagai institusi pendidikan (yang sesuai tugas pokok dan fungsinya) telah, sedang dan akan melaksanakan kegiatan pemantapan, pengembangan dan pertumbuhan yang berkelanjutan untuk mencapai kebutuhan spesialisasi dan kompetensinya.

Kurikulum yang ditetapkan di ATK atau secara khusus pada Prodi DTS disusun berdasarkan Keputusan Menteri Pendidikan Nasional Nomor 232/U/2000 tanggal 20 Desember 2000 tentang Pedoman Penyusunan Kurikulum Pendidikan Tinggi dan Penilaian Hasil Belajar. Kurikulum sepenuhnya mengacu pada kurikulum berbasis kompetensi yang dicirikan adanya fleksibilitas serta merupakan kombinasi antara mata kuliah inti dan mata kuliah institusional dengan dasar kompetensi yang dibangun. Demikian pula menyesuaikan kompetensi yang dibutuhkan lulusan dengan menitikberatkan pada: (1) Kedalaman pengetahuan dibidang teknologi kulit; produksi sepatu; sepatu atau alas kaki; dan bahan kulit, karet dan plastik; (2) Pengembangan berfikir secara global dan bertindak secara lokal; (3) Pengembangan daya analisis, kemampuan melaku- kan inovasi dan memecahkan masalah dalam rangka pengembangan keterampilan/ keahlian; (4) Pengembangan semangat juang dan kewirausahaan.

Pada data yang ditemukan pada dokumen roadmap reposisi dan pengembangan disebutkan bahwa peninjauan kurikulum dilakukan selama 4 tahun sekali, dengan dilakukan evaluasi jangka pendek untuk tiap semesternya. Peninjauan kurikulum Akademi Teknologi Kulit, terakhir kali dilakukan tahun 2009 dan disyahkan tahun 2010. Dalam evaluasi kurikulum tahun 2009 dilakukan pengembangan kurikulum dengan mempertimbangkan beberapa masukan dari para stakeholder.

Dalam melakukan pengembangan kurikulum dilakukan beberapa tahapan, dimulai dari pembuatan kuesioner yang dibagikan ke beberapa alumni dan pengguna alumni untuk mendapatkan beberapa masukan. Selain daripada itu data diperoleh juga dari beberapa perguruan tinggi yang lain hampir mirip/ prodi yang sejenis. Selanjutnya dari beberapa data tersebut dievaluasi visi dan misi masingmasing prodi serta kompetensi lulusan yang diharapkan, kemudian dibuat struktur kurikulumnya dengan berfokus pada: (1) Kesesuaian dengan kebutuhan industri; (2) Perbaikan 
keterkaitan antar mata kuliah; (3) Pembenahan pembentukan karakter lulusan; (4) Keterkaitan antar 4 prodi yang merupakan cerminan struktur industri perkulitan; (5) Penguatan dasardasar desain, sains dan keteknikan agar lulusan selalu bisa mengikuti perkembangan teknologi.

Kurikulum Program Studi Desain dan Teknoogi Sepatu (DTS) Akademi Teknologi Kulit (ATK) Yogyakarta mempunyai total SKS sebanyak 115, ini sudah termasuk 4 SKS Tugas Akhir atau TA

Berdasarkan uraian di atas tentang deskripsi singkat kurikulum pada Program Studi Desain dan Teknologi Sepatu telah menjelaskan bahwa kurikulum Program Studi Desain dan Teknologi Sepatu telah sesuai dengan tuntutan dunia kerja atau dunia industri. Kurikulum yang diaplikasikan pada prodi DTS cukup relevan atau sudah sesuai dengan kebutuhan dunia industri sebagaimana dikatakan oleh Ibu Hartati sebagai alumni Prodi DTS yang telah berwirausaha dan menjadi pimpinan pada perusahan sepatu Edward Colection dan Wahyu edi Wasono sebagai Owner Work Life Handicraf.

Tanggapan dari responden yang didapat melalui wawancara (sesuai pedoman wawancara), yakni dilakukan dengan wawancara singkat mengacu pada pedoman wawancara, yang terdiri dari beberapa pernyataan atau pertanyaan menunjukkan bahwa sebagian besar responden yang terdiri dari mahasiswa tingkat akhir yang telah menyelesaikan praktik industri pada beberapa industri sepatu dan alumni, baik yang bekerja pada instansi pemerintah atau swasta dan yang berwirausaha menyatakan kurikulum Program Studi Desain dan Teknologi sepatu sesuai dengan kebutuhan dunia kerja atau industri.

\section{Kepuasan alumni Prodi DTS ATK Yogyakarta}

Secara umum baik mahasiswa maupun lulusan atau alumni yang telah menyelesaiakan studi atau kuliahnya pada Prodi DTS ATK Yogyakarta merasa puas akan pengetahuan dan ketrampilan yang mereka peroleh. Hal ini ditunjukkan dari tanggapan yang disampaikan oleh para mahasiswa tingkat akhir yang telah selesai melakukan praktik kerja industri maupun alumni yang telah bekerja pada industri atau mereka yang telah berwirausaha mencip- takan pekerjaan sendiri dalam bidang sepatu atau perkulitan.

Berdasarkan data yang diperoleh dari beberapa hasil wawancara dengan responden mengenai kepuasan akan pengetahuan dan keterampilan, data yang diperoleh adalah bahwa sebagian besar responden baik dari mahasiswa tingkat akhir maupun lulusan menyatakan puas akan pengetahuan dan ketrampilan yang diperoleh dari pendidikan atau perkuliahan di prodi DTS ATK Yogyakarta. Data mengenai informasi kepuasan juga didapatkan dari pengguna, dalam hal ini adalah dunia usaha atau industri yang menggunakan lulusan atau alumni dari ATK, atau bahkan alumni sendiri sebagai pelaku dunia usaha yakni lulusan atau alumni yang berwiraswasta. Informasi yang didapatkan dari mereka menyatakan merasa puas dengan pengetahuan dan ketrampilan yang dikuasai oleh para mahasiswa atau lulusan.

Apabila dianalisis atau dihubungkan dengan realitas atau kondisi sarana dan prasarana yang dimiliki oleh prodi DTS, hal ini sangatlah relevan apabila responden menyatakan puas. Hal tersebut dikarenakan pada prodi DTS ATK Yogyakarta menyediakan fasilitas maupun kelengkapan sarana praktik yang memadai atau cukup presentatif yang disesuaikan dengan perkembangan peralatan yang digunakan pada perusahaan atau dunia usaha atau industri. Mahasiswa tidak hanya difasilitasi dengan fasilitas dan peralatan yang memadai, akan tetapi penggunaan fasilitas pendukung dan bahan praktik yang dibutuhkan untuk keperluan praktik persepatuan disediakan dengan jumlah yang cukup. Sehingga mahasiswa memungkinkan dapat praktik dengan bahan dan kelengkapan alat-alat yang memadai yang sesuai dengan standar dunia kerja atau industri.

Hal lain yang mendukung pernyataan dari pada responden adalah bahwa dalam kenyataannya tidak sedikit permintaan dari dunia usaha atau industri yang meminta untuk menarik atau merekrut para alumni ATK Yogyakarta untuk dapat bekerja pada perusahaannya. Hal ini sangatlah realistik dikarenakan pada setiap kegiatan praktek kerja lapangan, mahasiswa banyak yang diterjunkan untuk dapat melaksanakan praktek kerja lapangan di perusahanperusahan besar bidang perkulitan. 


\section{KESIMPULAN DAN SARAN}

\section{Kesimpulan}

Hasil penelitian dan kajian tentang pengelolan Prodi Desain dan Teknologi Sepatu (DTS) di Akademi Teknologi Kulit (ATK) Yogyakarta dapat diambil kesimpulan sebagai berikut:

\section{Pengelolaan Program Studi DTS}

1. Akademi Teknologi Kulit (ATK) merupakan unit pendidikan vokasi di bawah Pusat Pendidikan dan Pelatihan (Pusdiklat) Industri Kementerian Perindustrian RI yang bertugas mendidik tenaga Ahli Madya Teknologi Kulit (A.Md TK)

2. Kedudukan Progran Studi DTS dalam pengelolaannya atau struktur organisasinya berada di bawah direktur ATK. Akan tetapi pengkoordinasian tanggung jawab, tugas dan wewenang secara langsung berada di bawah PD (Pembantu Direktur) 1 yang mengurusi dan membidangi akademik atau pendidikan.

3. Struktur Program Studi DTS di lingkungan ATK terdiri atas: Ketua Program Studi, Sekretaris Program Studi, dan Koordinator workshop. Dosen Program Studi, teknisi, dan laboran.

4. Pengelolaan Program Studi Desain dan Teknologi Sepatu mengacu pada Amanat UU Sisdiknas No. 20 tahun 2003 yakni tata kelola sistem pendidikan nasional yang diarahkan pada peningkatan mutu serta relevansi dan effisiensi manajemen pendidikan untuk menghadapi globalisasi, yaitu: dari traditional learning ke knowledge creator and moral force; dari random planning ke strategic planning; dan dari comparative ke competitive. Adanya perubahan tata kelola perguruan tinggi tersebut, akan membawa institusi menjadi Good Corporate Governance ( $G C G)$. Pengertian GCG, adalah tata kelola korporasi yang memberikan jaminan atas hasil dari suatu proses dan sistem yang dialami dengan berlandaskan pada prinsip fairness, transparancy, responscibility, dan accountability. Indikator utama dari $G C G$ adalah: autonomy, competitiveness, organizational health, inovation, entrepreun- ership, stakeholders, control system and development.

5. Tanggung jawab, tugas, dan wewenang pengelolaan Program Studi DTS meliputi hal-hal yang berhubungan dengan proses KBM, pemberdayaan SDM di Program Studi DTS, dan Pengelolaan Workshop.

6. Secara umum pengelolaan laboratorium atau workshop sepatu yang di koordinasi oleh seorang Kepala Workshop sepatu dapat dilaksanakan dengan baik. Dalam menjalankan tugasnya ketua atau kepala Workshop sepatu Program Studi DTS dibantu oleh seorang dosen, laboran dan teknisi dan bertanggung jawab kepada ketua program Studi.

7. Pengelolaan SDM Program Studi DTS baik dosen, staf dan karyawan secara spesifik tidak dikelola oleh internal program studi sendiri. Akan tetapi pengelolaan SDM dilaksanakan pada tingkat akademi yakni dilakukan oleh manajemen ATK secara umum melalui usulan dari Program Studi.

\section{Kesesuaian Kurikulum}

Kurikulum yang diterapkan di Program Studi DTS adalah kurikulum berbasis kompetensi dengan tujuan untuk menghasilkan lulusan yang mempunyai kemampuan pengetahuan dan keterampilan sesuai dengan kompetensi yang dibutuhkan industri, melaksanakan penelitian yang aplikatif dan inovatif agar dapat diterapkan industri, menyediakan jasa pelayanan teknis dan pelatihan untuk tenaga kerja di industri, serta melakukan kegiatan usaha produksi.

Prodi DTS menerapkan kurikulum berbasis kompetensi yang berlandaskan Production Based Education and Training (PBET). Kurikulum sepenuhnya mengacu pada kurikulum berbasis kompetensi yang dicirikan adanya fleksibilitas serta merupakan kombinasi antara mata kuliah inti dan mata kuliah institusional dengan dasar kompetensi yang dibangun. Evaluasi atau peninjauan kurikulum dilaksanakan secara periodik dalam jangka 4 (empat) tahunan bersama prodi lain yang ada di ATK. Dalam evaluasi kurikulum dilakukan pengembangan kurikulum dengan mempertimbangkan beberapa masukan dari para stakeholder. 
Berdasarkan data hasil penelitian yang diambil dari pernyataan responden, yakni para alumni maupun pihak Industri/ usaha menyatakan bahwa tanggapan mereka akan kurikulum yang DTS cenderung positif. Artinya kurikulum Prodi DTS sudah sesuai dengan kebutuhan Dunia Industri/ usaha.

\section{Kepuasan alumni atas pengetahuan dan ketrampilan}

Data hasil penelitian yang diambil dari pernyataan responden, yakni para mahasiswa tingkat akhir yang telah selesai melaksanakan kegiatan praktek kerja industri berdasarkan pernyataan yang disampaikan melalui wawancara menyatakan sebagian besar dari mereka menyatakan puas akan pengetahuan dan keterampilan yang diperoleh dari Program Studi DTS ATK Yogyakarta. Alasan mereka menyatakan puas, karena dengan bekal pengetahuan dan keterampilan yang mereka peroleh, mereka dapat melaksanakan PI dengan baik.

Data hasil penelitian yang diambil dari pernyataan responden, yakni alumni Program Studi DTS yang telah berwiraswasta atau sebagai pelaku usaha atau Industri mereka menyatakan puas akan pengetahuan dan keterampilan yang didapat atau diajarkan di ATK pada Program Studi DTS. Terbukti dengan keterampilan dan pengetahuan yang mereka pelajari di Program Studi DTS mereka dapat menciptakan lapangan pekerjaan sendiri atau berwiraswasta. Tenaga kerja yang mereka rekrut, yang merupakan lulusan dari Akademi Teknologi Kulit dapat mereka pekerjakan dengan baik.

Para lulusan umumnya merasa puas atas bekal pengetahuan dan keterampilan yang diperoleh selama studi di Program Studi DTS ATK Yogyakarta. Ada sebagian dari mereka yang menjadi tenaga kerja atau bekerja pada dunia usaha, dan ada sebagian dari mereka yang dapat berwirausaha dalam bidang perkulitan.

\section{Saran}

ATK Yogyakarta, lebih khusus Program Studi DTS saat ini dan masa yang akan mendatang tentu akan mendapatkan tantangan yang semakin berat. Tantangan tersebut di samping karena kemajuan ilmu pengetahuan dan teknologi, juga datang dari semakin tingginya tuntutan masyarakat maupun tuntutan dari dunia usaha/ industri.

Sebuah investasi pendidikan tentunya membutuhkan pendanaan atau pembiayaan yang banyak dan terus menerus, sehingga transparansi dan akuntabilitas adalah hal yang menjadi tuntutan wajib dalam sebuah pengelolaan atau manajemen. Oleh karenanya hendaklah lembaga mulai mencari solusi atas pendanaan untuk dapat mendukung keberlanjutan organisasi. Sehingga pengelolaan manajemen organisasi yang tangguh, baik sangat diperlukan dalam pengelolaan institusi pendidikan.

Kepada semua pemegang kebijakan, kiranya dapat mengambil kebijakan yang mementingkan kepentingan untuk masa depan dan perkembangan yang lebih baik, guna memberikan kontribusi yang positif pada perkembangan dan pengembangan institusi.

Kurikulum yang berbasis kompetensi kiranya dapat dijalankan semaksimal mungkin, dengan harapan potensi lulusan dapat berkembang secara optimal memenuhi tuntutan pasar dan masyarakat. Lulusan diharapkan memiliki keahlian atau kompetensi yang sesuai dengan bidangnya. Bekal keterampilan dan ilmu pengetahuan sangat bermanfaat bagi lulusan untuk menjalankan kehidupan terjun di tengah-tengah masyarakat.

\section{DAFTAR PUSTAKA}

Beane, James. A., Teopfer. Conrad.F., \& Alessi. Samuel.J. (1986). Curriculum planning and development. Boston: Allyn and Bacon Inc.

Bush, Tony. (2008). Leadership and management development in education. T.J International, Padstow, Cornwall

Fandy Tjiptono. (2005). Prinsip-prinsip total quality service. Yogyakarta: Andi Offset

Frederick M. Nafukho, Carroll M. Graham, and Kit Kacirek. (2010). Education service agency audits: Reinforcing the need for systematic evaluation. International Journal of Vocational Education and Training. Volume 17, Number 2.Kent State University. ISSN: 1075-2455. 
Griffin, Ricky. W. (2004). Management. Boston: Houghton Mifflin Company

Handi Irawan. (2002). 10 Prinsip kepuasan pelanggan., Jakarta: Gramedia Pustaka Utama.

Hasibuan Malayu, (2003). Manajemen: dasar, pengertian, dan masalah. Jakarta: Bumi Aksara.

Hikmat. (2009). Manajemen pendidikan. Bandung: CV Pustaka setia.

Noeng Muhajir. (2000). Metodologi penelitian kualitatif. Yogyakarta: Rake Sarasen.

Oemar Hamalik. (2003). Kurikulum dan pembelajaran. (Edisi revisi). Jakarta: PT Bumi Aksara.

Oliva, Peter. F. (1992). Developing the curriculum. (Third edition). New York: Harper Colins Publisher

Oliver. (1997). Manajemen pelanggan. Yogyakarta: Andi Offset

Riandi.(2013). Pengelolaan laboratorium. Diambil tanggal 8 Juni 2013, dari http://file.upi.edu/Direktori/FPMIPA/JUR._PEND._BIOLOGI/ 196305011988031RIANDI/Bahan_Kuliah/Pengelolaan_Laboratorium.pdf.
Schoderbek, P.P, Cosier, R.A, Aplin, J.C.(1988). Management. London: Harcourt Brace Jovanovich Publishers.

Statuta Akademi Teknologi Kulit Yogyakarta Tahun 2003.

Stephen P. Robbins. (2002). Organisation theory concepts and cases. Prentice Hall

Suharsimi Arikunto. (2012). Manajemen pendidikan. Yogyakarta: Aditya Media bekerjasama dengan FIP UNY.

Syahrizal Abbas. (2008). Manajemen perguruaan tinggi. Aceh: Prenada Media Group.

Terry, Geoge. (2010). Dasar-dasar management: Jakarta: PT. Bumi Aksara

Undang Undang No. 20. Tahun 2003. Sistem pendidikan nasional. Jakarta: Depdikbud. 